\title{
The Vi antigen of Salmonella typhi: molecular analysis of the viaB locus
}

\author{
SuZanne Kolyva, Hervé Waxin and Michel Y. PopofF* \\ Institut Pasteur, Service des Entérobactéries, Unité INSERM 199, 28 rue du Docteur Roux, 75724 Paris \\ Cedex 15, France
}

(Received 9 September 1991; revised 28 October 1991; accepted 12 November 1991)

\begin{abstract}
Strains of Salmonella typhi isolated from the blood of patients with typhoid fever invariably express a capsular polysaccharide, termed the $\mathrm{Vi}$ antigen. Vi antigen expression is controlled by two separate chromosomal loci, viaA and viaB. The via $A$ locus is commonly found in enteric bacteria. In contrast, the viaB locus appears to be specific to Vi-expressing strains of Salmonella and Citrobacter. Here the cloning, expression and analysis of viaB determinants from $S$. typhi Ty2 is described. Whole-cell DNA from strain Ty2 was size-fractionated and cloned into the pLA2917 cosmid vector. A recombinant cosmid, pVT1, conferring a Vi-positive phenotype upon Escherichia coli and upon the Vi-non-expressing strain Ty21a of $S$. typhi, was characterized and used for further studies. Transposon Tn5 insertion mutagenesis demonstrated that the Vi-antigen-encoding region on pVT1 consisted of a $15 \mathrm{~kb}$ fragment. A subclone, designated pVT3, which contained an $18 \mathrm{~kb}$ insert, was sufficient to confer $\mathrm{Vi}$ antigen expression upon $E$. coli and $S$. typhi Ty21a. Results of recombination experiments indicated that this DNA sequence was the viaB locus of $S$. typhi Ty2. In E. coli SE5000 maxicells, the viaB determinants encoded at least eight polypeptides, with molecular masses of $80,65,59,48,44,39,35$ and $28 \mathrm{kDa}$. Functional characterization of viaB mutations in S. typhi Ty2 suggested that the 80 and $65 \mathrm{kDa}$ proteins were required for cellsurface localization of the Vi antigen.
\end{abstract}

\section{Introduction}

The Vi antigen, discovered by Felix \& Pitt (1934), is a capsular polysaccharide found mainly in Salmonella typhi and $S$. paratyphi $\mathrm{C}$, as well as in a few strains of $S$. dublin and Citrobacter freundii (Felix \& Pitt, 1936; Baker et al. 1959). Purified Vi antigen from $S$. typhi is a linear homopolymer of $\alpha$-1,4 2-deoxy-2- $N$-acetylgalacturonic acid variably $O$-acetylated at the $\mathrm{C} 3$ position (Heyns \& Kiessling, 1967; Daniels et al., 1989). Determinants of Vi antigen occupy two widely separated chromosomal loci, designated viaA and viaB (Johnson et al., 1965; Snellings et al., 1981). Functional via $A$ genes, located at $43 \mathrm{~min}$ on the chromosome of $S$. typhi (Johnson et al. 1966), are present not only in Vi-expressing strains of Salmonella and Citrobacter, but also in Escherichia coli and $S$. typhimurium (Johnson \& Baron, 1969; Johnson et al., 1965). The viaB locus, specific to Vi-expressing strains, maps adjacent to the melibiose ( $\mathrm{mel}$ ) and inositol (inl) utilization genes at $92 \mathrm{~min}$ on the chromosome of $S$. typhi (Johnson \& Baron, 1969; Johnson et al., 1965, 1966; Snellings et al., 1977). In C. freundii, Vi-expressing strains undergo a rapid and reversible transition between

\footnotetext{
* Author for correspondence. Tel. (1) 45688346; fax (1) 45688837.
}

forms that express the $\mathrm{Vi}$ antigen and forms that do not (Snellings et al., 1981). The genetic switch mechanism that controls reversible expression of $\mathrm{Vi}$ antigen is linked to the viaB locus in Citrobacter (Snellings et al., 1981). It is now known that this reversible expression of the $\mathrm{Vi}$ antigen of $C$. freundii in $E$. coli is caused by specific insertion and excision of an IS 1 -like insertion element (Ou et al., 1988). In contrast, expression of $\mathrm{Vi}$ antigen in $S$. typhi is stable. However, Vi-non-producing variants can be isolated from Vi-producing strains of $S$. typhi after repeated subcultures on solid medium. Reversion of such non-expressing variants to Vi-expressing forms is rarely seen (Snellings et al., 1977).

The present study was undertaken to better define the viaB locus of $S$. typhi. The cloning, analysis and expression of the DNA sequence corresponding to the $v i a B$ locus of $S$. typhi are presented in this paper.

\section{Methods}

Bacterial strains and plasmids. S. typhi strain Ty2 was from the collection of the WHO collaborating centre for reference and research on Salmonella (Institut Pasteur, Paris). This strain expressed the $\mathrm{Vi}$ antigen and possessed the $0: 9,12$ somatic factors. S. typhi strain Ty21a, a UDP-glucose 4-epimerase (galE) mutant of strain Ty2 
(Germanier \& Fürer, 1975), possessed several additional mutations and, notably, did not synthesize Vi antigen (Cryz et al., 1989). S. typhi Hfr strain TD7 (cys try inl), which expressed Vi antigen, and $S$. typhimurium strain $\mathrm{HMXSr}$ (his metA $\mathrm{Sm}^{\mathrm{R}}$ ), which produced acid from inositol, were previously used by Johnson et al. (1965) for genetic mapping of Vi antigen determinants in Salmonella. E. coli HB101 (Boyer \& Roulland-Dussoix, 1969) (hsdR hsdM recAl3 supE44 lacZ4 leuB6 proA2 thi-1 rpsL) was used as host for cloning experiments. $E$. coli S17-1 (Simon et al., 1983) (pro thi recA hsdR chromosomal RP4-2; Tn $1::$ ISR $1 \mathrm{Tc}:: \mathrm{Mu} \mathrm{Km}:: \mathrm{Tn} 7$ ) carried the transfer genes of plasmid RP4 integrated in the chromosome and allowed mobilization of cloning vectors in which the Mob (oriT) region of plasmid RP4 was cloned (e.g. pLA2917 and pSUP203; see below). E. coliS17-1::Tn5 was a mutant of E. coli S17-1 with transposon Tn 5 inserted in the chromosome (Denefle et al., 1987). E. coli $\mathrm{K} 12-\mathrm{Nl}$ was a spontaneous nalidixic acid-resistant mutant of E. coli C600 (Appleyard, 1954). E. coli SE5000 (Silhavy et al., 1984) $\left(\mathrm{F}^{-}\right.$araD139 $\Delta($ argF-lac)U169 rpsL150 relA1 flbB5301 deoC1 ptsF 25 rbsR recA56) was used as the source of maxicells.

The cosmid pLA2917 (Allen \& Hanson, 1985) was used for gene library construction. Plasmids pSUP203 (Simon et al., 1983) and pUC19 (Vieira \& Messing, 1982) were used as subcloning vehicles.

Media and growth conditions. Strains were routinely grown at $37^{\circ} \mathrm{C}$ in tryptic soy broth (TSB) or on tryptic soy agar (TSA; Diagnostics Pasteur). When necessary, antibiotics were added at the following concentrations: ampicillin (Ap), $100 \mu \mathrm{g} \mathrm{ml}^{-1}$; chloramphenicol (Cm), $30 \mu \mathrm{g} \mathrm{ml}^{-1}$; kanamycin $(\mathrm{Km}), 50 \mu \mathrm{g} \mathrm{ml}^{-1}$; nalidixic acid $(\mathrm{Nl})$, $100 \mu \mathrm{g} \mathrm{ml}^{-1}$; streptomycin (Sm), $500 \mu \mathrm{g} \mathrm{ml}^{-1}$; and tetracycline (Tc), $20 \mu \mathrm{g} \mathrm{m}^{-1}$. Production of acid from inositol was tested in peptone water containing $1 \%(\mathrm{w} / \mathrm{v})$ inositol and bromophenol blue (Diagnostics Pasteur). Antigenic formulae of Salmonella strains were verified by slide-agglutination in antisera specific for $\mathrm{O}$ somatic factors and $\mathrm{Vi}$ antigen (Diagnostics Pasteur).

Assays for Vi antigen. The presence of $\mathrm{Vi}$ antigen associated with the cell surface was determined by slide-agglutination. The presence of cell-surface-associated $\mathrm{Vi}$ antigen was further confirmed by testing the sensitivity of the bacteria to Vi-specific phage IV (Craigie \& Felix, 1947). A drop (approximately $10^{8}$ phage particles) was spotted onto a TSA plate that was seeded with the bacterial culture to be tested. After overnight incubation at $37^{\circ} \mathrm{C}$, cell lysis was observed only in the case of bacteria expressing surface-associated $\mathrm{Vi}$ antigen.

To detect accumulation of intracellular $\mathrm{Vi}$ antigen or release of this polymer into culture supernatant, cells were grown in $10 \mathrm{ml}$ TSB at $37^{\circ} \mathrm{C}$ for $18 \mathrm{~h}$ with vigorous shaking. The $\mathrm{OD}_{600}$ was recorded and adjusted to $\mathrm{OD}_{600}=4$ (about $2 \times 10^{9}$ viable cells $\mathrm{ml}^{-1}$ ) with fresh TSB. After centrifugation $(7500 \mathrm{~g}$ for $15 \mathrm{~min}$ ), the supernatant was carefully collected and filter-sterilized. The bacterial pellet was washed twice in $0.85 \%(\mathrm{w} / \mathrm{v}) \mathrm{NaCl}$ and suspended in $0.85 \% \mathrm{NaCl}$ at $\mathrm{OD}_{600}=4$. After disruption by sonication, unbroken cells were removed by centrifugation at $20000 \mathrm{~g}$ for $15 \mathrm{~min}$. The resulting supernatant (sonicated extract) was filter-sterilized. The protein concentration of sonicated extract was determined using a Coomassie protein assay kit (Pierce) and the extracts were standardized with $0.85 \% \mathrm{NaCl}$ to give $150 \mu \mathrm{g}$ protein $\mathrm{ml}^{-1}$. Presence of soluble $\mathrm{Vi}$ antigen in these preparations was demonstrated by immunoprecipitation using a single-diffusion method (Blair et al., 1970). Briefly, in a narrow-bore test tube, $100 \mu$ l of either culture supernatant or sonicated extract was overlaid onto $100 \mu \mathrm{l}$ agar gel containing $50 \mu \mathrm{l} \mathrm{Vi}$ antiserum mixed with $50 \mu \mathrm{l} 0.8 \%(\mathrm{w} / \mathrm{v})$ lowmelting-point agarose (Appligene) in $0.85 \% \mathrm{NaCl}$. After overnight incubation at room temperature, formation of a visible precipitate at the interface of reactants demonstrated the presence of $\mathrm{Vi}$ soluble antigen in culture supernatant or sonicated extract. Using a highly purified preparation of Vi antigen (Typhim Vi; Institut Merieux, Lyon, France) as a reference standard, it was possible to detect as little as $0.2 \mu \mathrm{g}$ soluble $\mathrm{Vi}$ antigen $\mathrm{ml}^{-1}$.
DNA manipulation and molecular cloning. Small-scale isolation of plasmid DNA was carried out as described by Birnboim \& Doly (1979) for $E$. coli strains and as described by Kado \& Liu (1981) for Salmonella strains. For large-scale isolation, the latter technique was used. DNA was further purified by centrifugation through a caesium chloride/ ethidium bromide density gradient. Plasmids and their restriction products were routinely analysed on horizontal $0.7 \%(w / v)$ agarose gels in Tris/borate buffer ( $89 \mathrm{~mm}$-Tris base, $89 \mathrm{~mm}$-boric acid, $2.5 \mathrm{~mm}$ EDTA; pH 8.0).

The methods used for constructing and manipulating recombinant DNA were essentially those of Maniatis et al. (1982). To obtain a recombinant cosmid library, chromosomal DNA from $S$. typhi Ty2 was partially digested with the restriction endonuclease Sau3A and DNA fragments were separated by gel electrophoresis. Fragments with an average size of $30 \mathrm{~kb}$ were recovered by electroelution and ligated to the Bglll dephosphorylated site of the cosmid pLA2917. The ligation mixture was packaged into bacteriophage $\lambda$ particles and used to infect $E$. coli HB101 under conditions specified by the manufacturer (In Vitro Packaging System for Lambda DNA; Amersham).

Restriction endonucleases and T4 DNA ligase were purchased from Amersham and calf-intestinal alkaline phosphatase was from Boehringer Mannheim.

Tn5 transposon-insertion mutagenesis. Tn 5 mutagenesis was performed as previously described (Norel et al., 1989). Briefly, recombinant plasmid DNA to be tagged by Tn 5 was transformed into $E$. coli S17-1::Tn5. Transformants were selected on TSA plates supplemented with appropriate antibiotics and were then mated with $E$. coli K 12-N1. Transconjugants were selected and purified on TSA plates containing $\mathrm{N} 1, \mathrm{Km}$ and required antibiotics. Tn5-tagged derivatives were subsequently analysed with restriction endonucleases.

Genetic exchange. Plasmid transformation in E. coli and Salmonella was performed by the method of Humphreys et al. (1979). Large recombinant plasmids, constructed with cosmid pLA2917 and plasmid pSUP203 as cloning vectors, were introduced into Salmonella recipient strains by conjugation using plate matings (Willetts, 1984). As a first step, recombinant DNA was introduced into $E$. coli $\mathrm{S} 17-1$ by transformation. The recombinant plasmid was then transferred by conjugation from $E$. coli $\mathrm{S} 17-1$ to Salmonella strains. Conjugation was carried out overnight at $37^{\circ} \mathrm{C}$.

DNA-DNA hybridization and probe preparation. DNA-DNA hybridization was performed on Hybond $\mathrm{N}$ membranes as recommended by the supplier (Amersham). The probe was radiolabelled with [ $\left.{ }^{32} \mathrm{P}\right] \mathrm{dCTP}$ (specific activity $3000 \mathrm{Ci} \mathrm{mmol}^{-1}, 111 \mathrm{TBq} \mathrm{mmol}^{-1}$; Amersham) by using the Pharmacia oligolabelling system.

Analysis of proteins expressed in maxicells. Analysis of plasmidencoded proteins was performed in $E$. coli SE5000, a maxicellproducing strain. Preparation of maxicells, labelling of plasmidencoded proteins with $\left[{ }^{35}\right.$ S $]$ methionine (Amersham), preparation of whole-cell extracts, SDS-PAGE (final acrylamide concentration $10 \%$, $w / v)$, and visualization of polypeptides by fluorography were carried out as described by Silhavy et al. (1984). Molecular masses of proteins were estimated using ${ }^{14} \mathrm{C}$-labelled molecular mass standards (Amersham).

\section{Results}

Screening of recombinant cosmid library

Bacteriophage $\lambda$ transducing particles carrying recombinant cosmid molecules with fragments $(25-35 \mathrm{~kb})$ of 


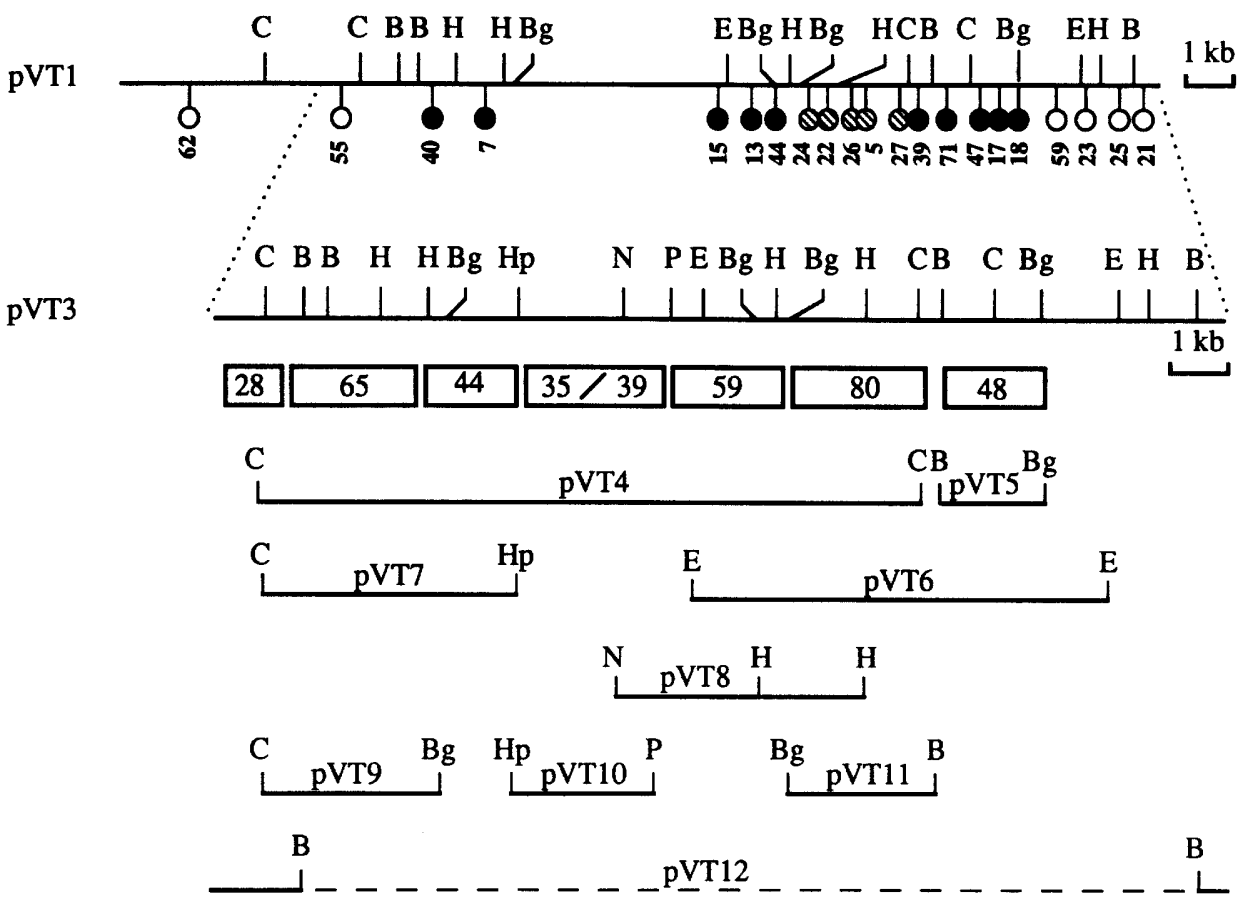

Fig. 1. Physical map of plasmids pVT1 and pVT3, Tn5-insertion localization, viaB locus subclones and estimated positions of viaB genes. Plain lines represent $S$. typhi Ty2 DNA. Dashed lines indicate deleted sequences in recombinant plasmids. Circles represent TnS insertions: open circle, Vi-positive phenotype; filled circle, Vi-negative phenotype; hatched circle, Vi-intermediate phenotype (see text). Boxes, drawn to scale, represent estimated positions of viaB genes. The molecular masses (kDa) of the corresponding proteins are indicated inside the boxes. Restriction sites: B, BamHI; Bg, BglII; C, ClaI; E, EcoRI; H, HindIII; Hp, HpaI; N, NcoI; P, PstI. Only $\mathrm{Hp}, \mathrm{N}$ and $\mathrm{P}$ sites used for constructing recombinant plasmids are indicated.

S. typhi Ty2 total DNA were prepared and used to transduce E. coli $\mathrm{HB} 101$. About 500 Tc-resistant and $\mathrm{Km}$-sensitive transductants were screened for $\mathrm{Vi}$ antigen expression by slide-agglutination with $\mathrm{Vi}$ antiserum. Two clones were strongly agglutinated by the antiserum, indicating the presence of cell surface-associated Vi antigen. Subcultures of these two clones were lysed by the Vi-specific phage IV. Soluble Vi antigen was also found in culture supernatants and in sonicated extracts.

The two Vi-expressing clones of $E$. coli HB101 harboured recombinant plasmids designated pVT1 and pVT2. The BamHI, BglII, ClaI, EcoRI and HindIII restriction sites of pVT1 and pVT2 were located by single and double restriction endonuclease digestions. This analysis showed that pVT1 and pVT2 carried a $22 \mathrm{~kb}$ and a $20 \mathrm{~kb}$ DNA insert, respectively. Comparison of the physical maps of pVT1 and pVT2 showed that they shared a common DNA sequence of about $19 \mathrm{~kb}$. Plasmids pVT1 and pVT2 conferred a Vi-positive phenotype upon $E$. coli $\mathrm{K} 12-\mathrm{Nl}, E$. coli $\mathrm{S} 17-1, E$. coli S17-1::Tn5 and $S$. typhi Ty21a. Plasmid pVT1 was chosen as the prototype for subsequent studies (Fig. 1).
Location of the $p V T 1$ sequence required for $V i$ antigen expression in E. coli

To define the smallest DNA fragment able to confer a Vi-positive phenotype upon E. coli, transposon $\operatorname{Tn} 5$ was randomly inserted into plasmid pVT1 using $E$. coli $\mathrm{S} 17-1:: \mathrm{Tn} 5$ as the delivery system and $E$. coli $\mathrm{K} 12-\mathrm{N} 1$ as the recipient strain. The sites of $\mathrm{Tn} 5$ insertions were identified by restriction endonuclease analysis of the pVT1 derivatives. The location of transposons selected for further study is indicated on the map of pVT1 in Fig. 1. Tn5-tagged plasmids will be hereafter designated by pVT1 : : followed by the Tn 5 insertion number (see Fig. 1). The phenotype of $E$. coli K12-N1 (pVT1::Tn5) mutants was assessed by slide-agglutination and by the Vi phage IV test. It is not known why transposon Tn5 could not be inserted in the $4.2 \mathrm{~kb}$ region between insertions 7 and 15.

The pVT1::Tn5 derivatives could be classified into three groups as indicated in Fig. 1. The six derivatives of the first group conserved the ability to confer a Vipositive phenotype upon $E$. coli $\mathrm{K} 12-\mathrm{Nl}$ (agglutination in 
Vi antiserum and lysis by phage IV). The Tn 5 insertions in these derivatives were localized to two regions: from insertion 55 to the left end of the pVT1 insert, and from insertion 59 to the right end of the insert. In the second group, there were ten derivatives that had lost the capacity to confer a Vi-positive phenotype upon the host strain. These $E$. coli $\mathrm{K} 12-\mathrm{N} 1$ (pVT1 ::Tn5) mutants were not agglutinated in $\mathrm{Vi}$ antiserum and were resistant to lysis by Vi phage IV. This result defined two DNA sequences required for expression of $\mathrm{Vi}$ antigen associated with the cell surface: a $6.8 \mathrm{~kb}$ region between insertions 40 and 44 , and a $3.8 \mathrm{~kb}$ region between insertions 18 and 39 . The five pVT1::Tn 5 derivatives of the third group contained insertions clustered within a $2.3 \mathrm{~kb}$ sequence (from insertions 24 to 27). They conferred an intermediate phenotype upon $E$. coli K12-N1. These mutants were partially and slowly agglutinated in $\mathrm{Vi}$ antiserum; but they were resistant to the lytic activity of phage IV. These results suggested that a $15 \mathrm{~kb}$ DNA sequence of pVTl insert was necessary for $\mathrm{Vi}$ antigen expression in $E$. coli $\mathrm{K} 12-\mathrm{Nl}$.

The $15 \mathrm{~kb}$ sequence of plasmid pVT1 able to confer a Vi-positive phenotype upon $E$. coli was subcloned in vector pSUP203. Plasmid pVT1 DNA was partially digested with Sau3A endonuclease and ligated to the BamHI dephosphorylated site of pSUP203. This mixture was used to transform $E$. coli HB101. Of 50 transformants tested, one agglutinated Vi antiserum and was lysed by $\mathrm{Vi}$ phage IV. This Vi-expressing clone harboured a recombinant plasmid, designated pVT3, which contained an $18 \mathrm{~kb}$ insert. A physical restriction map of plasmid pVT3 is presented in Fig. 1.

\section{Construction and analysis of viaB mutants of S. typhi Ty2}

To test the effect of $\mathrm{Tn} 5$ insertions on $\mathrm{Vi}$ antigen expression in $S$. typhi, insertions 59, 18, 27, 22, 13, 15, 7, 40 and 55 were recombined from plasmid pVT1 derivatives into the chromosome of strain $\mathrm{Ty} 2$ in the following manner. Plasmid pVT1::Tn5 DNA was transformed into $E$. coli S17-1. Transformants were selected on Tc and $\mathrm{Km}$-TSA plates. The correct position of $\mathrm{Tn} 5$ insertion was verified by restriction endonuclease mapping. The plasmid was then transferred from $E$. coli S17-1 to $S$. typhi Ty2 by conjugation. Transconjugants, selected on $\mathrm{Km}$-TSA plates, were tested for Tc-resistance. One colony resistant to $\mathrm{Km}$ and susceptible to Tc was selected and the correct position of $\mathrm{Tn} 5$ insertion was verified by DNA-DNA hybridization analysis using pVT1 as radiolabelled probe (data not shown). Loss of the cosmid vector after the recombination event was verified using pLA2917 as probe. This colony was then assayed for $\mathrm{Vi}$ antigen production by slide-agglutination and with Vi phage IV. These mutants will be referred to as $S$. typhi Ty $2:$ : followed by the $\operatorname{Tn} 5$ insertion number.

Results of $\mathrm{Vi}$ antigen detection were similar for $S$. typhi Ty2::Tn5 and E. coli(pVT1::Tn5) mutants, except for insertions 22 and 27 (Fig. 1). These two insertions, which conferred an intermediate $\mathrm{Vi}$ phenotype upon $E$. coli (pVT1::22/27), completely eliminated detection of cell-surface-associated Vi antigen in $S$. typhi Ty2::22/27 mutants (no agglutination in Vi antiserum; no lysis by $\mathrm{Vi}$ phage IV). Vi-negative $S$. typhi Ty2::18/27/22/13/15/7/40 mutants possessed $O: 9$ and $\mathrm{O}: 12$ somatic factors, as verified by slide-agglutination in specific antisera.

The $S$. typhi viaB locus occupies a position close to determinants of inositol utilization. To confirm that the $\mathrm{Vi}$ antigen determinants of the pVT1 insert corresponded to the viaB locus, it was determined whether $\operatorname{Tn} 5$ insertion 13 was linked to inl on the chromosome of $S$. typhi. For this purpose, insertion 13 from derivative pVT1::13 was recombined into the chromosome of $S$. typhi $\mathrm{Hfr}$ TD7 (Inl-; Vi positive). This $S$. typhi $\mathrm{Hfr}$ TD7 ::13 mutant ( $\mathrm{Inl}^{-}$; Vi negative; $\mathrm{Km}^{\mathrm{R}}$ ) was mated with $S$. typhimurium $\mathrm{HMXSr}\left(\mathrm{Inl}^{+} ; \mathrm{Sm}^{\mathrm{R}}\right)$. Transconjugants were selected on $\mathrm{Sm}$ and $\mathrm{Km}$-TSA plates. Of $100 \mathrm{Km}^{\mathrm{R}}$ transconjugants examined, 65 had lost the capacity to produce acid from inositol. This result indicated that the $\mathrm{Km}$ marker was linked to the inl locus and strongly suggested that insertion 13 lay within the functional region of the viaB locus of $S$. typhi Hfr TD7. Taken together, these data confirmed that the $15 \mathrm{~kb}$ sequence of pVT1 required to confer a Vi-positive phenotype to $E$. coli contained the viaB locus of $S$. typhi Ty2.

\section{Identification of the products encoded by the viaB locus}

To identify the polypeptides encoded by the viaB locus, plasmid pVT3 was introduced into the $E$. coli maxicellproducing strain SE5000. Protein labelling of maxicells indicated eight polypeptides with molecular masses of $80,65,59,48,44,39,35$ and $28 \mathrm{kDa}$ that were produced by SE5000(pVT3) but not by SE5000(pSUP203) (Fig. 2). Expression of proteins from various subclones of plasmid $\mathrm{pVT} 3$ and from $\operatorname{Tn} 5$ derivatives was further analysed to localize the corresponding genes (Figs 1, 2 and 3). Plasmid pUC19 was used as the subcloning vehicle.

Plasmid pVT4, carrying the central $10.7 \mathrm{~kb}$ ClaI fragment of pVT3, encoded six polypeptides, of 80,65 , $59,44,39$ and $35 \mathrm{kDa}$ (Fig. 2). Plasmid pVT6, containing the $7.2 \mathrm{~kb} E c o$ RI fragment of pVT3, encoded two polypeptides, of 48 and $80 \mathrm{kDa}$. Plasmid pVT5 expressed the $48 \mathrm{kDa}$ product and plasmid pVT11, the $80 \mathrm{kDa}$ polypeptide (Fig. 2). From pVT1 ::22 and pVT1 ::27, the $7.2 \mathrm{~kb}$ EcoRI fragment containing Tn 5 insertion 22 or 27 (see Fig. 1) was subcloned into pUC19. The $80 \mathrm{kDa}$ 


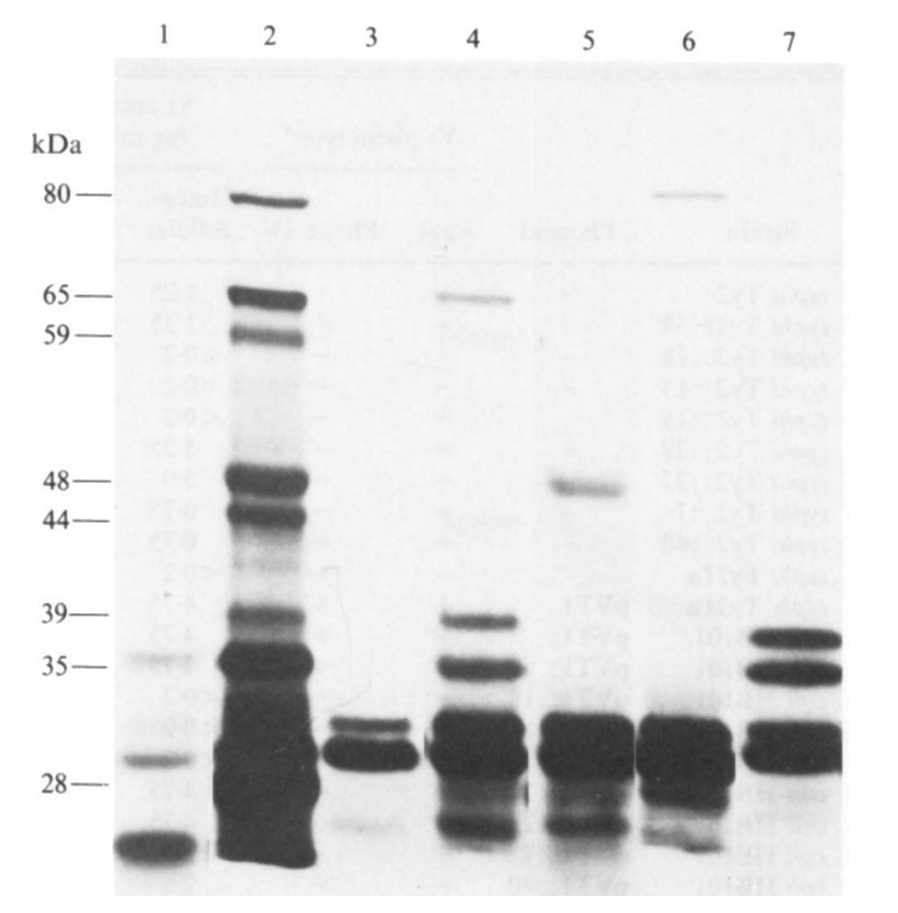

Fig. 2. Proteins expressed in E. coli SE5000 maxicells by pSUP203 (lane 1), pVT3 (lane 2), pUC19 (lane 3), pVT4 (lane 4), pVT5 (lane 5), pVT11 (lane 6), and pVT10 (lane 7). Molecular masses of proteins $(\mathrm{kDa})$ are indicated.

protein was no longer expressed by these two derivatives; it was not possible to examine production of the $48 \mathrm{kDa}$ protein as several Tn5-specific polypeptides migrated in this region. The 39 and $35 \mathrm{kDa}$ products were expressed by pVT10 (Figs 1 and 2). Subclones expressing only one of these two products were not obtained. Products of 65,44 and $42 \mathrm{kDa}$ were expressed by pVT7 (Fig. 3). Plasmid pVT9 encoded the $65 \mathrm{kDa}$ protein (Fig. 3). This product was no longer expressed by recombinant plasmids containing the $7.7 \mathrm{~kb} C l a \mathrm{I}-E c o \mathrm{RI}$ fragment tagged by Tn5 insertion 7 or 40 (see Fig. 1); expression of the 44 and $42 \mathrm{kDa}$ products could not be examined as they co-migrated with Tn5-encoded polypeptides. Plasmids pVT3, 4, and 7 synthesized the $44 \mathrm{kDa}$ product, whereas plasmid pVT9 did not (Figs 2 and 3 ). This result strongly suggested that the right-hand part of pVT7 encoded the $44 \mathrm{kDa}$ protein. The $42 \mathrm{kDa}$ product was not encoded by plasmids pVT3, 4 and 9 (Figs 2 and 3). This product was only visualized after expression of pVT7 in maxicells (Fig. 3). Plasmids pVT4 and pVT8 expressed a $59 \mathrm{kDa}$ product (Figs 2 and 3),

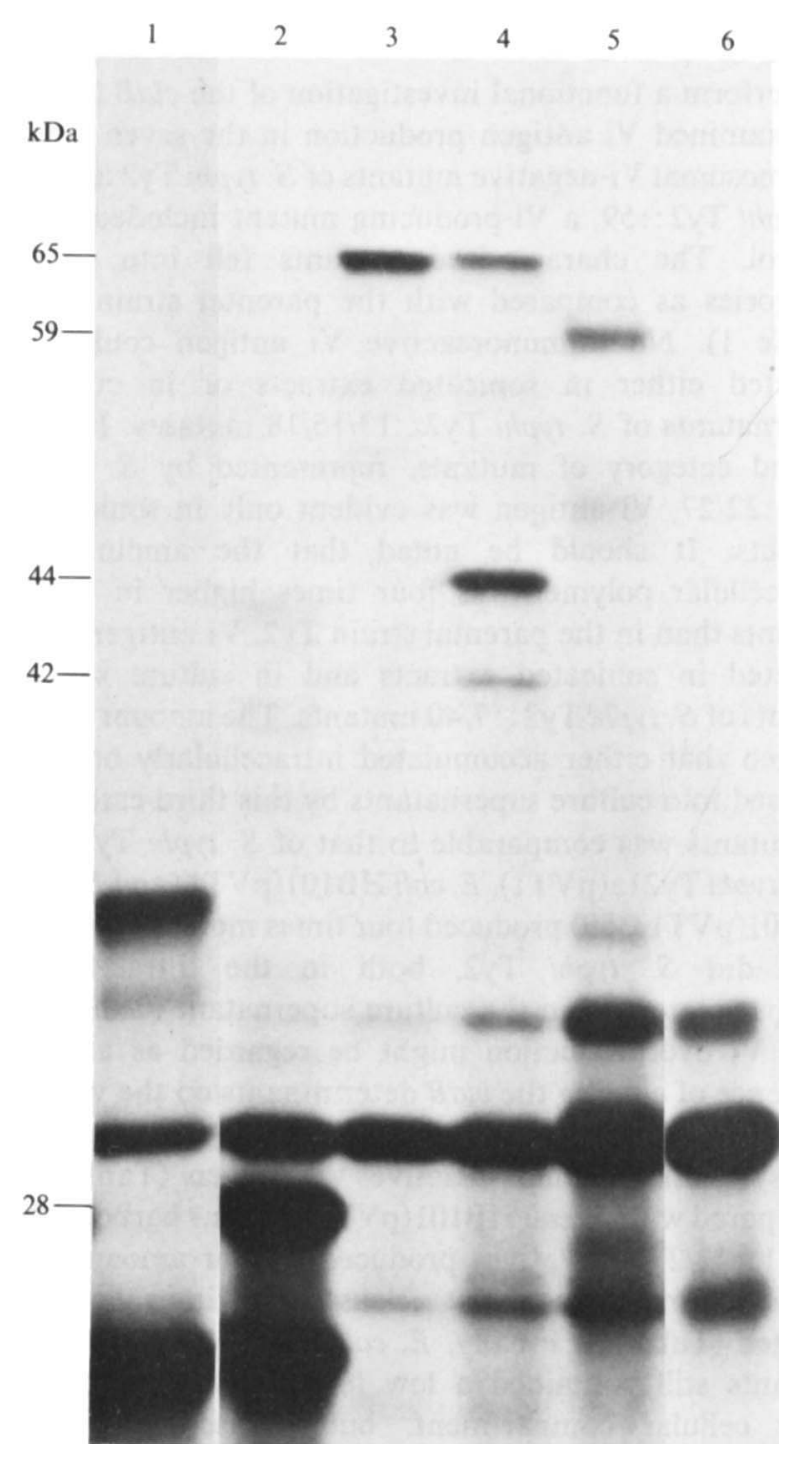

Fig. 3. Proteins expressed in E. coli SE5000 maxicells by pSUP203 (lane 1), pVT12 (lane 2), pVT9 (lane 3), pVT7 (lane 4), pVT8 (lane 5), and pUC19 (lane 6). Molecular masses of proteins (kDa) are indicated.

whereas plasmid pVT6 did not. It was concluded that the $59 \mathrm{kDa}$ protein coding sequence overlapped the $E c o \mathrm{RI}$ site located in the central region of pVT3 and pVT8. The $28 \mathrm{kDa}$ polypeptide was expressed by pVT12, a derivative constructed after BamHI deletion of pVT3. As the $S$. typhi DNA sequence $(0.3 \mathrm{~kb})$ in the right-hand part of pVT1 2 was not long enough to encode a $28 \mathrm{kDa}$ product, it was suggested that the $28 \mathrm{kDa}$ protein was encoded by the left-hand end of pVT12 (see Fig. 1). 
Functional characterization of viaB mutations in $S$. typhi Ty 2 and E.coli $(p V T I)$

To perform a functional investigation of the viaB locus, we examined Vi antigen production in the seven Tn5chromosomal Vi-negative mutants of $S$. typhi Ty2 and in $S$. typhi Ty2::59, a Vi-producing mutant included as a control. The characterized mutants fell into three categories as compared with the parental strain Ty2 (Table 1). No immunoreactive $\mathrm{Vi}$ antigen could be detected either in sonicated extracts or in culture supernatants of $S$. typhi Ty $2:: 13 / 15 / 18$ mutants. In the second category of mutants, represented by $S$. typhi Ty $2:: 22 / 27, \mathrm{Vi}$ antigen was evident only in sonicated extracts. It should be noted that the amount of intracellular polymer was four times higher in these mutants than in the parental strain Ty2. Vi antigen was detected in sonicated extracts and in culture supernatants of $S$. typhi Ty $2:: 7 / 40$ mutants. The amount of Vi antigen that either accumulated intracellularly or was released into culture supernatants by this third category of mutants was comparable to that of $S$. typhi Ty2.

S. typhi Ty21a(pVT1), E. coli HB101(pVT1) and E. coli HB101(pVT1 : :59) produced four times more Vi antigen than did $S$. typhi Ty2, both in the intracellular compartment and in the culture supernatant (Table 1). This $\mathrm{Vi}$ overproduction might be regarded as a consequence of cloning the viaB determinants on the vector pLA2917. E. coli HB101(pVT1::13/15/18) mutants did not synthesize immunoreactive $\mathrm{Vi}$ antigen (Table 1 ). Compared with E. coli HB101(pVT1), strains harbouring pVT1::22/27 derivatives produced similar amounts of intracellular polymer, but released 10 times less $\mathrm{Vi}$ antigen (Table 1). Finally, E. coli HB101(pVT1::7/40) mutants still contained a low level of $\mathrm{Vi}$ antigen in their cellular compartment, but released twice as much immunoreactive polysaccharide as did $E$. coli HB101(pVT1).

\section{Discussion}

The objectives of this work were to define the genetic organization and the functions of the viaB locus of $S$. typhi. The recombinant cosmid pVT1, carrying a $22 \mathrm{~kb}$ insert of $S$. typhi chromosomal DNA, conferred a Vi positive phenotype upon several strains of $E$. coli and upon the Vi-non-expressing strain $S$. typhi Ty21a. Further molecular cloning experiments and $\operatorname{Tn} 5$ mutagenesis revealed that the genetic determinants of the viaB locus were located within a $15 \mathrm{~kb}$ DNA fragment on pVT1 and on the $S$. typhi Ty 2 chromosome. By mating experiments, this sequence was confirmed to be located closely adjacent to inl determinants on the $S$. typhi
Table 1. Amount of Vi antigen detected in the intracellular compartment of bacteria or released into culture supernatant

\begin{tabular}{|c|c|c|c|c|c|}
\hline \multirow[b]{2}{*}{ Strain } & \multirow[b]{2}{*}{ Plasmid } & \multicolumn{2}{|c|}{ Vi phenotype* } & \multicolumn{2}{|c|}{$\begin{array}{l}\text { Vi antigen } \\
\left(\mu \mathrm{g} \mathrm{ml}^{-1}\right)\end{array}$} \\
\hline & & Aggl. & Phage IV & $\begin{array}{l}\text { Intra- } \\
\text { cellular }\end{array}$ & $\begin{array}{l}\text { Super- } \\
\text { natant }\end{array}$ \\
\hline S. typhi $\mathrm{Ty} 2$ & - & + & + & 1.25 & 10 \\
\hline S. typhi Тy2::59 & - & + & + & 1.25 & 10 \\
\hline S. typhi Тy2::18 & - & - & - & $<0 \cdot 2$ & $<0.2$ \\
\hline S. typhi Тy $2:: 13$ & - & - & - & $<0 \cdot 2$ & $<0.2$ \\
\hline S. typhi Тy $2:: 15$ & - & - & - & $<0.2$ & $<0 \cdot 2$ \\
\hline S. typhi Ty $2:: 22$ & - & - & - & $5 \cdot 25$ & $<0.2$ \\
\hline S. typhi Ty2::27 & - & - & - & $5 \cdot 0$ & $<0.2$ \\
\hline S. typhi Тy2::7 & - & - & - & 0.75 & $12 \cdot 25$ \\
\hline S. typhi Ty $2:: 40$ & - & - & - & 0.75 & $12 \cdot 25$ \\
\hline S. typhi Ty2la & - & - & - & $<0.2$ & $<0.2$ \\
\hline S. typhi Ty2la & pVT1 & + & + & 4.75 & 39.75 \\
\hline E. coli $\mathrm{HB} 101$ & pVT1 & + & + & 4.75 & 39.75 \\
\hline E. coli $\mathrm{HB} 101$ & pVT1::59 & + & + & $4 \cdot 75$ & 39.75 \\
\hline E. coli $\mathrm{HB} 101$ & pVT1::18 & - & - & $<0.2$ & $<0.2$ \\
\hline E. coli $\mathrm{HB} 101$ & pVT1::13 & - & - & $<0 \cdot 2$ & $<0 \cdot 2$ \\
\hline E. coli $\mathrm{HB} 101$ & pVT1::15 & - & - & $<0.2$ & $<0 \cdot 2$ \\
\hline E. coli $\mathrm{HB} 101$ & pVT1::22 & + & - & 4.75 & 4.75 \\
\hline E. coli $\mathrm{HB} 101$ & pVT1::27 & + & - & 4.75 & $2 \cdot 5$ \\
\hline E. coli $\mathrm{HB} 101$ & pVT1::7 & - & - & $2 \cdot 5$ & $79 \cdot 0$ \\
\hline E. coli HB101 & pVT1::40 & - & - & $2 \cdot 5$ & $79 \cdot 0$ \\
\hline
\end{tabular}

* Presence of cell surface-associated $\mathrm{Vi}$ antigen determined by agglutination (Aggl.) and by lysis with Vi-phage IV (Phage IV): +, positive reaction; -, negative reaction.

chromosome. The viaB locus of $C$. freundii has been cloned by Rubin et al. (1985). They demonstrated that a $18 \mathrm{~kb}$ fragment was sufficient to confer a Vi-positive phenotype upon E. coli HB101. Although the viaB locus of $S$. typhi Ty2 has already been cloned, the restriction map of the recombinant cosmid was not published and its genetic organization was not analysed further (Cryz et al., 1989).

Plasmid pVT3, a subclone of plasmid pVT1 with a $18 \mathrm{~kb}$ insert, conferred $\mathrm{Vi}$ antigen expression upon $E$. coli SE5000. In this maxicell-producing system, pVT3 expressed eight polypeptides, of $80,65,59,48,44,39,35$, and $28 \mathrm{kDa}$. After subcloning experiments, it was possible to map the coding sequences for the proteins of $80,65,59,48,44$ and $28 \mathrm{kDa}$ within the via $B$ locus. The 39 and $35 \mathrm{kDa}$ products were expressed by pVT10, which contained a $2.5 \mathrm{~kb} H p a \mathrm{I}-$ Pst I fragment of the viaB locus (Fig. 1). Subclones expressing these two products independently were not obtained, and no Tn5 insertion in this HpaI-PstI fragment could be isolated on pVT1. Consequently, the respective positions of the DNA sequences encoding these two products could not be accurately determined. The possibilities exist that: (1) the $2.5 \mathrm{~kb} \mathrm{HpaI-Pst} \mathrm{I} \mathrm{fragment} \mathrm{encodes} \mathrm{a} \mathrm{protein} \mathrm{that}$ migrated on a $10 \%(\mathrm{w} / \mathrm{v})$ SDS-polyacrylamide gel as two products of apparent molecular mass 39 and $35 \mathrm{kDa}$; (2) 
the 39 and $35 \mathrm{kDa}$ coding genes are co-transcribed; and (3) one of these products is required for the expression or the stability of the other. The $42 \mathrm{kDa}$ product was expressed by plasmid pVT7 in maxicells, but not by plasmids pVT3, 4 and 9 (Fig. 1). This polypeptide might result from translation re-initiated at a secondary start codon or from premature termination of translation within the $44 \mathrm{kDa}$ protein coding sequence. The $28 \mathrm{kDa}$ product did not appear to be associated with $\mathrm{Vi}$ antigen synthesis, as insertion 55 , located by restriction mapping in this protein-coding sequence (Fig. 1), did not affect Vi expression in S. typhi Ty $2:: 55$ or in E. coli(pVT1::55). Nevertheless, it was not possible to examine expression of the $28 \mathrm{kDa}$ polypeptide using a subclone with this Tn5 insertion as this protein co-migrated with the $\mathrm{Km}$ resistance gene product from $\mathrm{Tn} 5$.

The mode of biosynthesis and biogenesis of the $\mathrm{Vi}$ antigen remain unknown. In order to address this problem, representative Tn5 mutants were studied further. S. typhi Ty2::22/27 mutants which did not express the $80 \mathrm{kDa}$ polypeptide accumulated intracellular $\mathrm{Vi}$ antigen but were devoid of capsular polysaccharide at the cell surface and did not release antigen into culture supernatant. We propose that in $S$. typhi, the $80 \mathrm{kDa}$ protein might act in the transport of the polysaccharide chains across the cytoplasmic membrane to the cell surface or in the maturation of the intracellular $\mathrm{Vi}$ antigen. In contrast, insertion $22 / 27$ on pVT1 in E. coli did not abolish expression of the polymer at the cell surface or its release into the culture supernatant. However, these mutants released four times less $\mathrm{Vi}$ antigen than $E$. coli(pVT1). The fact that $E$. coli(pVT1::22/27) mutants were not lysed by the Vispecific phage IV indicated that the $\mathrm{Vi}$ antigen evidenced by agglutination was incapable of acting as a $\mathrm{Vi}$ phage IV receptor and for this reason might not be cell-associated. It was inferred that insertion 22 or 27 on plasmid pVT1 in E. coli resulted in synthesis of only intracellular $\mathrm{Vi}$ antigen and might have caused polymer leakage by a passive and non-specific process. In $E$. coli(pVT1::7/40) and $S$. typhi Ty2::7/40 mutants, Vi antigen was detected in the cytoplasm and in the culture supernatant but not at the cell surface. Insertion 7/40 resulted in a decrease of $\mathrm{Vi}$ antigen accumulated within the cell and in an increase of $\mathrm{Vi}$ antigen released into supernatants when compared to parental strains (Table 1). These mutants did not express the $65 \mathrm{kDa}$ polypeptide. We suggest that the $65 \mathrm{kDa}$ product may be a protein necessary for cell-surface localization of the $\mathrm{Vi}$ antigen. Studies are under way in our laboratory to further define the role of the 80 and $65 \mathrm{kDa}$ proteins and to identify other viaB-encoded functions pertinent to assembly, translocation and regulation mechanisms.

Like $S$. typhi, many invasive organisms possess a capsular polysaccharide that interferes with the host's specific and non-specific defences. These surface antigens are usually of high molecular mass and comprise predominantly hexosaminuronic acids. Such polysaccharides have been found in $E$. coli strains expressing $\mathrm{K}$ antigen, Haemophilus influenzae types $\mathrm{b}, \mathrm{d}$ and $\mathrm{e}$, Staphylococcus aureus strain Smith and Streptococcus pneumoniae (Williamson \& Zamenhof, 1963; Liau et al., 1974; Robbins et al., 1974; Leontein et al., 1983; Boulnois \& Jann, 1989). Capsule or capsule-like structures are considered a major virulence factor of these bacteria (Robbins \& Robbins, 1984). Nevertheless the relationship of these capsular polymers to bacterial invasiveness remains an unresolved problem. Further analysis should provide new insights into the specific virulence-associated functions of capsular-polysaccharide antigens. In that light, the results presented in this study may help to focus attention for further research on the pathogenic role of $S$. typhi Vi antigen.

We thank Agnes Labigne, Françoise Norel and Richard Ferrero for critical review of this manuscript.

\section{References}

Allen, L. N. \& Hanson, R. S. (1985). Construction of broad-hostrange cosmid cloning vectors: identification of genes necessary for growth of Methylobacterium organophilum on methanol. Journal of Bacteriology 161, 955-962.

APPLEYARD, R. K. (1954). Segregation of new lysogenic types during growth of a double lysogenic strain derived from Escherichia coli K 12. Genetics 39, 440-452.

Baker, E. E., Whiteside, R. E., Basch, R. \& Derow, M. A. (1959). The $\mathrm{Vi}$ antigen of the Enterobacteriaceae. II. Immunologic and biologic properties. Journal of Immunology 83, 680-686.

Birnboim, H. C. \& Doly, J. (1979). A rapid alkaline extraction procedure for screening recombinant plasmid DNA. Nucleic Acids Research 7, 1513-1523.

Blair, J. E., Lennette, E. H. \& Truant, J. P. (1970). Manual of Clinical Microbiology. Bethesda, MD: American Society for Microbiology.

BoulNoIS, G. J. \& JANN, K. (1989). Bacterial polysaccharide capsule synthesis, export and evolution of structural diversity. Molecular Microbiology 3, 1819-1823.

Boyer, H. W. \& Roulland-Dussorx, D. A. (1969). A complementation analysis of the restriction and modification of DNA in E. coli. Journal of Molecular Biology 41, 459-472.

Craigie, J. \& Felix, A. (1947). Typing of typhoid bacilli with Vi bacteriophage. Lancet i, 824-827.

Cryz, S. J., Jr, Fürer, E., Baron, L. S., NoOn, K. F., Rubin, F. A. \& KOPECKO, D. J. (1989). Construction and characterization of a $\mathrm{Vi}$ positive variant of the Salmonella typhi live oral vaccine strain Ty21a. Infection and Immunity 57, 3863-3868.

Daniels, E. M., SChneerson, R., Egan, W. M., SzU, S. C. \& Robbins, J. B. (1989). Characterization of the Salmonella paratyphi C Vi polysaccharide. Infection and Immunity 57, 3159-3164.

Denefle, P., Kush, A., Norel, F., Paquelin, A. \& Elmerich, C. (1987). Biochemical and genetic analysis of the nifHDKE region of Rhizobium ORS571. Molecular and General Genetics 207, 280-287.

Felix, A. \& PITt, R. M. (1934). A new antigen of B. typhosus. Lancet 227, 186-191.

Felix, A. \& PITt, K. M. (1936). The Vi antigens of various Salmonella types. British Journal of Experimental Pathology 17, 81-86. 
GERMANIER, R. \& FürER, E. (1975). Isolation and characterization of galE mutant Ty21a of Salmonella typhi: a candidate strain for a live, oral typhoid vaccine. Journal of Infectious Diseases 131, 553-558.

HeYNS, K. \& KiessLiNG, G. (1967). Strukturaufklarung des Vi-antigens aus Citrobacter freundii (E. coli) 5396/38. Carbohydrate Research 3, 340-352.

Humphreys, G. O., Weston, A., Brown, M. G. M. \& SAunders, J. R. (1979). Plasmid transformation in Escherichia coli. In Transformation 1978, pp. 254-279. Edited by S. W. Glover \& L. O. Buttler. Oxford: Cotswold Press.

Johnson, E. M. \& Baron, L. S. (1969). Genetic transfer of the Vi antigen from Salmonella typhosa to Eschericia coli. Journal of Bacteriology 99, 355-359.

Johnson, E. M., Krauskopf, B. \& Baron, L. S. (1965). Genetic mapping of $\mathrm{Vi}$ and somatic antigenic determinants in Salmonella. Journal of Bacteriology 90, 302-308.

Johnson, E. M., Krauskopf, B. \& Baron, L. S. (1966). Genetic analysis of the viA-his chromosomal region in Salmonella. Journal of Bacteriology 92, 1457-1463.

KaDo, C. I. \& LIU, S. T. (1981). A rapid procedure for detection and isolation of large and small plasmids. Journal of Bacteriology 145, $1365-1373$.

LEONTEIN, K., LiNDBERG, B. \& LoNNGREN, J. (1983). Structural studies of the capsular polysaccharide from Streptococcus pneumoniae type 12A. Carbohydrate Research 114, 257-266.

Liau, D. F., Melly, M. A. \& Hash, J. H. (1974). Surface polysaccharide from Staphylococcus aureus $\mathbf{M}$ that contains taurine, D-aminogalacturonic acid and D-fucosamine. Journal of Bacteriology 119, 913-922.

Maniatis, T., Fritsch, E. F. \& Sambrook, J. (1982). Molecular Cloning, a Laboratory Manual. Cold Spring Harbor, NY: Cold Spring Harbor Laboratory

Norel, F., Coynault, C., Miras, I., Hermant, D. \& Popoff, M. Y. (1989). Cloning and expression of plasmid DNA sequences involved in Salmonella serotype Typhimurium virulence. Molecular Microbiology 3, 733-743.
Ou, J. T., Baron, L. S., Rubin, F. A. \& Kopecko, D. J. (1988). Specific insertion and deletion of insertion sequence 1 -like DNA element causes the reversible expression of the virulence capsular antigen $\mathrm{Vi}$ of Citobacter freundii in Escherichia coli. Proceedings of the National Academy of Sciences of the United States of America 85, 4402-4405.

Robbins, J. D. \& RobBins, J. B. (1984). Reexamination of the protective role of the capsular polysaccharide ( $\mathrm{Vi}$ antigen) of Salmonella typhi. Journal of Infectious Diseases 150, 436-449.

Robbins, J. B., McCraken, G. H., JR, Gotschlich, E. C., Ørskov, F. ØrsKov, I. \& HaNson, L. A. (1974). Escherichia coli K1 capsular polysaccharide associated with neonatal meningitis. New England Journal of Medicine 290, 1216-1220.

Rubin, F. A., Kopecko, D. J., Noon, K. F. \& Baron, L. S. (1985). Development of a DNA probe to detect Salmonella typhi. Journal of Clinical Microbiology 22, 600-605.

Silhavy, T. J., Berman, M. L., Enquist, L. W. (1984). Experiments with Gene Fusions. Cold Spring Harbor, NY: Cold Spring Harbor Laboratory.

Simon, R., Priefer, U. \& Puhler, A. (1983). A broad host range mobilization system for in vivo genetic engineering: transposon mutagenesis in gram negative bacteria. Biotechnology 1, 784-791.

SNellings, N. J., Johnson, E. M. \& Baron, L. S. (1977). Genetic basis of $\mathrm{Vi}$ antigen expression in Salmonella paratyphi C. Journal of Bacteriology 131, 57-62.

Snellings, N. J., Johnson, E. M., Kopecko, D. J., Collins, H. H. \& BARON, L. S. (1981). Genetic regulation of variable Vi antigen expression in a strain of Citrobacter freundii. Journal of Bacteriology 145, 1010-1017.

Vieira, J. \& Messing, J. (1982). The pUC plasmids, an M13 mp7derived system for insertion mutagenesis and sequencing with synthetic universal primers. Gene 19, 259-268.

Williamson, A. R. \& ZamenhoF, S. (1963). The type-specific substance of Haemophilus influenzae type d: the natural occurrence of glucosamine uronic acid. Journal of Biological Chemistry 238 2255-2258.

WilletTs, N. (1984). Conjugation. Methdos in Microbiology 17, 33-59. 